\title{
Hybridising Medicine: Illness, Healing and the Dynamics of Reciprocal Exchange on the Upper Guinea Coast (West Africa)
}

\author{
PHILIP J. HAVIK * \\ Unidade de Clínica Tropical/Fundação para a Ciência e Tecnologia (FCT), Instituto de Higiene e \\ Medicina Tropical (IHMT), New University of Lisbon (UNL), Universidade Nova de Lisboa, \\ Rua da Junqueira, 100, 1349-008 Lisbon, Portugal
}

\begin{abstract}
The present article seeks to fill a number of lacunae with regard to the study of the circulation and assimilation of different bodies of medical knowledge in an important cultural contact zone, that is the Upper Guinea Coast. Building upon ongoing research on trade and cultural brokerage in the area, it focuses upon shifting attitudes and practices with regard to health and healing as a result of cultural interaction and hybridisation against the background of growing intra-African and Afro-Atlantic interaction from the fifteenth to the late seventeenth century. Largely based upon travel accounts, missionary reports and documents produced by the Portuguese Inquisition, it shows how forms of medical knowledge shifted and circulated between littoral areas and their hinterland, as well as between the coast, the Atlantic and beyond. It shows that the changing patterns of trade, migration and settlement associated with Mandé influence and Afro-Atlantic exchange had a decisive impact on changing notions of illness and therapeutic trajectories. Over the centuries, cross-cultural, reciprocal borrowing contributed to the development of healing kits employed by Africans and non-African outsiders alike, which were used and brokered by local communities in different locations in the region.
\end{abstract}

Keywords: Illness, Healing, Knowledge, Hybridisation, West-Africa, Guinea Bissau Region

\section{Introduction}

The question of disease in the tropics has been the subject of considerable debate since the eighteenth century, when enlightened botanists, climatologists, doctors, officials, as well as missionaries, began probing hitherto unexplored regions of the globe. What followed was the classification of climates, ecosystems and populations, thereby giving rise to new fields

* Email address for correspondence: philip.havik@ihmt.unl.pt

The author wishes to acknowledge the financial support of the Fundação para a Ciência e Tecnologia (FCT) in Portugal, and to thank anonymous referees for their insightful remarks and suggestions on earlier versions of this paper, and Alexander Medcalf for his diligence and care during the proof stages. 
of scientific knowledge. The micro-biological discoveries which took place in the late 1800s revolutionised scientific knowledge of health and disease in tropical environments. It culminated in the paradigm shift from humoral and miasmatic perspectives to the new fields of parasitology and epidemiology, which set out to determine the causes of pathologies such as yellow fever, malaria, smallpox, cholera, tuberculosis, leprosy, typhoid fever and sleeping sickness. At the same time, international sanitary conventions and colonial expansion into Asia and Africa imbued this new field of research with the notions of public health and hygiene. One of the principal tasks assigned to tropical medicine was to provide favourable conditions for colonial settlement by employing medical and pharmaceutical innovations.

However, before the enlightened drive towards the classification of nature and the scramble for empire, early European expansion had already resulted in encounters with the tropics without the benefit of modern medical science. The image of Africa that eventually became inscribed into Western perspectives on the tropics, that is 'the white man's grave', was a stark reality before the 1800 s, when the mortality rates as a result of diseases such as malaria, yellow fever, cholera and yaws were high. ${ }^{1}$ Indeed, early modern travel accounts and missionary reports make no secret of the hazardous conditions that prevailed in these outposts of empire. ${ }^{2}$ Nevertheless, with rare exceptions, health issues have tended to be a marginal aspect of studies on pre-or proto-colonial formations in former imperial possessions in Africa.

Areas of Portuguese influence, however, provide from the earliest period of contact in the mid-1400s an almost uninterrupted chronology of documentation, which the present article explores in order to trace developments regarding ethnobotanical and medical knowledge in West Africa. The present article aims to fill gaps in the social historiography and medical anthropology of West Africa and the Senegambia and Guinea Bissau region (GBR) in particular ${ }^{3}$ by exploring written documentation from the mid-1400s. Travel accounts, secular and missionary reports and evidence produced by the Portuguese Inquisition cover the period from early contact to the late 1600s. They demonstrate that different cultural kits of phytotherapeutical and medical knowledge, including healing and divinatory practices, circulated in the aforementioned regions among autochthons and strangers. The extensive borrowing, adaptation and hybridisation of methods and cures for treating a wide range of diseases and health conditions shows that distinctions between African and Western knowledge were far from clear, and that boundaries were fluid. Taking its cue from contemporary approaches based upon the twin notions of cultural hybridisation and medical pluralism, the article analyses processes of cross-cultural borrowing and assimilation that took place in a contact zone against the background of Afro-Atlantic trade and settlement from the late 1400 s to the late $1600 s^{4}$

\footnotetext{
${ }^{1}$ See Philip Curtin, The Image of Africa (Madison, WI: University of Wisconsin Press, 1964), 179.

2 Ibid., 177-9; also by Philip D. Curtin, Death by Migration: Europe's Encounter with the Tropical World in the Nineteenth Century (Cambridge/New York: Cambridge University Press, 1989) and Disease and Empire: The Health of European Troops in the Conquest of Africa (Cambridge and New York: Cambridge University Press, 1998).

${ }^{3}$ The Guinea Bissau region (GBR), a term first coined by Brooks (see note 33), refers to the area currently occupied by the Republic of Guinea Bissau and the Lower Casamance region in Senegal. The term Upper Guinea coast was proposed by Rodney (see note 36) for the area extending from the Senegal River in the north to the Sherbro River in the south.

${ }^{4}$ On contact zones, see Mary Louise Pratt, Imperial Eyes: Travel Writing and Transculturation (London and New York: Routledge, 2001).
} 


\section{Cross-Cultural Interaction and Hybrid Medical Practice}

The complex and intricate processes of cross-cultural interaction have fascinated many a researcher in the social sciences, most particularly since the 1950s, when Steward's culture change project produced a growing body of innovative research on cultural brokerage. ${ }^{5}$ Subsequently, concepts such as cultural brokerage found their way into the social sciences and left their mark on the study of non-Western societies. ${ }^{6}$ As a result, the agency of local actors and groups in diverse cultural contexts emerged as a key thread in comparative, multi-disciplinary and trans-disciplinary methodologies and epistemologies with respect to cross-cultural interaction.

One of the areas in which the notion of culture change had a lasting impact is that associated with the history and anthropology of medicine. Scholars have argued that medicine itself is a social and cultural system of knowledge embedded in social relations and institutions, thus encouraging cross-cultural comparisons. ${ }^{7}$ Empirical research on nonWestern medical systems has since unearthed a large variety of disease perceptions and aetiologies across the globe. ${ }^{8}$ The notion of bodies of medical knowledge as flexible 'adaptive systems' gradually took root in anthropological studies from the $1970 \mathrm{~s},{ }^{9}$ further benefiting from the innovative notion of medical pluralism which emerged in the course of the 1980s. ${ }^{10}$ These shifts in analysis eventually replaced the opposition of biomedical concepts of medicine to indigenous ones by introducing the notion of complementary and alternative medicine (CAM). They tend to stress the integrative aspects in medical knowledge and practice, reinforced by the focus on its circulation and on the agency of brokers and processes of role adaptation on the part of indigenous' healers, under the impact of Western medicine. ${ }^{11}$ This heightened awareness of connections and interactions posited the extensive borrowing between different societies and cultures over time, which led scholars to focus on hybrid and interactive 'polycultural' forms of knowledge and practice. $^{12}$

One of the most relevant epistemologies on cross-cultural interaction was that of creolisation, which provoked an ongoing debate on hybrid social and cultural

\footnotetext{
5 Julian H. Steward, Theory of Culture Change (Urbana, IL: University of Illinois Press, 1955).

${ }^{6}$ Philip J. Havik, 'The colonial encounter revisited: anthropological and historical perspectives on brokerage', in M. Cardeira da Silva (ed.), The Jill Dias Lessons (Lisbon: CRIA, 2013), 97-111.

7 Arthur Kleinman, 'Concepts and a Model of the Comparison of Medical Systems as Cultural Systems', Social Science and Medicine, XII, 1 (1978), 85-93.

${ }^{8}$ G.M. Foster, 'Disease Etiologies in Non-Western Medical Systems', American Anthropologist, LXXVIII (1976), 773-82.

${ }^{9}$ See Charles M. Leslie, Asian Medical Systems: A Comparative Study (Berkeley, CA: University of California Press, 1976); on adaptive systems, also see Frederick L. Dunn, 'Traditional Asian medicine and cosmopolitan medicine as adaptive systems', in Leslie, Asian Medical Systems, 133-158.

${ }^{10}$ Roy Porter, Health for Sale: Quackery in England, 1660-1850 (Manchester: Manchester University Press, 1989).

${ }^{11}$ See David Landy, 'Role Adaptation: Traditional Curers under the Impact of Western Medicine', American Ethnologist, 1, 1 (1974), 103-27; Lynn Schumaker et al. 'Introduction: Histories of Healing: Past and Present Medical Practices in Africa and the Diaspora', Journal of Southern African Studies, 33, 4 (2007), 707-14; Karen E. Flint, Healing Traditions: African Medicine, Cultural Exchange, and Competition in South Africa, 1820-1948 (Athens, OH: Ohio University Press, 2008); David Baranov, The African Transformation of Western Medicine and the Dynamics of Global Cultural Exchange (Philadelphia, PA: Temple University Press, 2008).

12 See Karen E. Flint, 'Indian-African Encounters: Polyculturalism and African Therapeutics in Natal, South Africa, 1886-1950s', Journal of Southern African Studies, 32, 2 (2006), 367-85.
} 
phenomena. ${ }^{13}$ The subject has been explored from socio-linguistic, anthropological and historical perspectives, transiting from specific geographical and social spaces to a global context. The critique of anthropology's failure to take into account the changes that took place during colonialism and recognise the fluidity, and hence the 'non-purity' of ethnic groups ${ }^{14}$ challenged deeply rooted post-Enlightenment classifications and typologies. This 'macro-anthropology of culture', as Hannerz called it, was preceded by Boasian ideas on the dynamics of cultural diffusion, and Braudelian notions of cultural interaction between greatly diverse societies in a given space. ${ }^{15}$ The diasporic model of a specific socio-cultural area advocated by Mintz and Price, as well as Gilroy's analysis of the ambivalent identities of communities shaped by the Black Atlantic, took their cues from these approaches. ${ }^{16}$ Linguistic research highlighted cultural standardisation in the form of Creole dialects and languages, ${ }^{17}$ positing the notion of societies as dynamic cultural continua resulting from overlapping, multi-layered, poly-ethnic discourses. ${ }^{18}$ Some have argued for the need to rethink Creole and creolisation concepts, returning to a Caribbean model and cautioning their application to global phenomena. ${ }^{19}$

Scholarly work on the Black Atlantic, which initially focused on the northern Atlantic, the American South and the Caribbean, ${ }^{20}$ has since branched out to encompass other contact zones, such as Latin America and Africa. ${ }^{21}$ Contact zones, such as the Caribbean, where long-term demographic and cultural creolisation took place, have provided a fertile ground for the debate on mutual acculturation and transculturation, for example with regard to health and healing. ${ }^{22}$ Studies of these medical encounters contain references to creolising tendencies at a cognitive level, including the emergence of 'medical mestizaje'

13 On creolisation studies, see Charles Stewart (ed.) Creolization: History, Ethnography, Theory (Walnut Creek, CA: Left Coast Press, 2007) and Robin Cohen and Paola Toninato (eds), The Creolization Reader (London: Routledge, 2009).

14 Jean-Loup Amselle, Mestizo Logics: Anthropology of Identity in Africa and Beyond (Stanford, CA: Stanford University Press, 1998).

15 See Alison Games, 'Atlantic History: Definitions, Challenges and Opportunities', American Historical Review, 111, 3 (2006), 741-57.

${ }^{16}$ Sidney Mintz and Richard Price, The Birth of Afro-American Culture, an Anthropological Perspective, (Boston, MA: Beacon, 1992); Paul Gilroy, The Black Atlantic: Modernity and Double Consciousness (London: Verso, 1993).

17 Anthony P. Naro, 'A Study on the Origins of Pidginization', Language, 54, 2 (1978), 314-47; Hugo Schuchardt, the Ethnography of Variation: Selected Writings on Pidgins and Creoles (Ann Arbor: Karoma, 1979).

18 Derek Bickerton, Dynamics of a Creole System (London: Cambridge University Press, 1975); Lee Drummond, 'The Cultural Continuum: A Theory of Intersystems', Man, 15 (1980), 352-74.

${ }^{19}$ See Aisha Khan, 'Journey to the Center of the Earth: The Caribbean as a Master Symbol', Cultural Anthropology, 16, 3 (2001), 271-302; also Stephan Palmié, 'Creolization and its Discontents', Annual Review of Anthropology, 35 (2006), 433-56. For a discussion of processes of creolisation in areas of Portuguese influence, see Philip J. Havik and Malyn Newitt (eds), Creole Societies in the Portuguese Colonial Empire (Newcastle: Cambridge Scholars Publishing, 2015).

${ }^{20}$ Gwendolyn Midlo-Hall, Africans in Colonial Louisiana: The Development of Afro-Creole Culture in the Eighteenth Century (Baton Rouge, LA: Louisiana State University Press, 1995) and Slavery and African Ethnicities in the Americas: Restoring the Links (Chapel Hill, NC: University of North Carolina Press, 2005).

${ }^{21}$ See Havik and Newitt, op. cit. (note 19); Nancy P. Naro et al. (eds), Cultures of the Lusophone Black Atlantic (New York: Palgrave, 2007); Caroline A. Williams, Bridging the Early Modern Atlantic: People, Products and Practices on the move (Farnham: Ashgate, 2009); Nicolau Parés and Roger Sansi-Roca (eds) Sorcery in the Black Atlantic (Chicago, IL, and London: Chicago University Press, 2011).

22 Karen McCarthy Brown, 'Healing relationships in the Caribbean', in H. Selin and H. Shapiro (eds), Medicine across Cultures: History and Practice of Medicine in Non-Western Cultures (New York: Kluwer, 2003), 285-303; Pablo F. Gómez, 'The Circulation of Bodily Knowledge in the Seventeenth-Century Black Spanish Caribbean', Social History of Medicine, 26, 3 (2013), 383-402. 
and 'Creole medicine'. ${ }^{23}$ These studies acknowledge the existence of a medicine market where indigenous people and strangers exchange products and information on illness and healing. They underlined the need for studying the socio-linguistic aspects and the cosmological aspects of cultural translation, for example with regard to healing in a hot/cold distinction of diseases reproduced by local practitioners and their clientele. ${ }^{24}$ The region of the Carolinas has also demonstrated how healing practices were assimilated by Africans, Europeans, and Euro- and Afro-Carolinians in their quest for survival, and how Creole medicine chests developed over time. ${ }^{25}$ Such practices firmly place the circulation and mutual borrowing of knowledge and 'creative cultural innovation' in a pluralistic environment. $^{26}$

In an African context, the histories of different local traditions and changing practices with regard to healing and divination have also focused on the multiplicity of therapies proposed by 'animist', Christian and Islamised health practitioners and pluralistic health-seeking trajectories. ${ }^{27}$ It showed that therapeutic and ethnic boundaries do not necessarily overlap, thus complicating attempts to elaborate therapeutic maps. ${ }^{28}$ Great advances have been made with regard to recording local medical traditions in West Africa since the 1970 s. $^{29}$ Research since the 1980 s on medicinal plants, their

${ }^{23}$ Martha Few, 'Medical mestizaje and the politics of pregnancy in colonial Guatemala, 1660-1730', in D. Bleichmar et al. (eds), Science, Power and the Order of Nature in the Spanish and Portuguese Empires (Stanford, CA: Stanford University Press, 2009), 132-46: 133.

${ }^{24}$ Alan Harwood, 'The Hot/Cold Theory of Disease: Implications for Treatment of Puerto Rican Patients, Journal of the American Medical Association, 216, 7 (1971), 1153-8; William R. Aho and Kimlian Minott, 'Creole and Doctor Medicine: Folk Beliefs, Practices and Orientations to Modern Medicine in a Rural and Industrial Setting in Trinidad Tobago', Social Science and Medicine, 11, 5 (1977), 349-55; Rocky Sexton, 'Cajun and Creole Treaters: Magico-Religious Folk Healing in French Louisiana', Western Folklore, 51, 3/4 (1992), 237-48; Paul Brodwin Medicine and Morality in Haiti: The Contest for Healing Power (Cambridge: Cambridge University Press, 1996); Wendy Torres-Avilez et al. 'Medicinal Plant Knowledge in the Caribbean Basin: A Comparative Study of Afrocaribbean, Amerindian and Mestizo Communities', Journal of Ethnobiology and Ethnomedicine, 11, 18 (2015).

25 Mary Galvin, 'Decoctions for Carolinians: the creation of a Creole medicine chest in colonial southern Carolina', in D. Buisseret and S. Reinhardt (eds), Creolization in the Americas (Arlington, TX: Texas University Press, 2000), 63-98.

26 Ibid., 82.

27 Steven Feierman and John M. Janzen, The Social Basis of Health and Healing in Africa (Berkeley and Los Angeles, CA, and London: University of California Press, 1992), 1-23.

28 Ibid., 2/3.

${ }^{29}$ George W. Harley, Native African Medicine, with Special Reference to its Practice in the Mano Tribe in Liberia (London: Frank Cass, 1970); Boubacar Barry, 'La Guerre des Marabouts dans la région du fleuve Sénégal de 1673 à 1677', Bulletin de l'Institut Fondamentale d'Afrique Noire, 33, 3 (1971), 564-89; Pascal James Imperato, African Folk Medicine: Practices and Beliefs of the Bambara and Other Peoples (Baltimore, MD: York, 1977); Z.A. Ademuragun et al. (eds), African Therapeutic Systems (Waltham, MA: ASA, 1979); Ismael H. Abdalla, Islam, Medicine and Practitioners in Northern Nigeria (Lewiston, NY: Edwin Mellen, 1997) and 'Diffusion of Islamic medicine into Hausaland', in Feierman and Janzen, op. cit. (note 27), 177-94; David Robinson and Jean-Louis Triaud (eds), Le Temps des Marabouts: Itinéraires et stratégies islamiques en Afrique Occidentale Française, 1880-1960 (Paris: Karthala, 1997); Jean-Pierre Olivier de Sardan, 'Illness Entities in West Africa', Anthropology \& Medicine, 5, 2 (1998), 193-217; Marguerite Dupire, 'Divination et pouvoir local: Variations sénégalaises, le "siltigi” Peul', Islam et Société au Sud du Sahara, 12 (1998), 109-28; Agnieszka Kedzierska and Benoît Jouvelet, Guérisseurs et féticheurs: La Médecine traditionnelle en Afrique de l'Ouest (Paris: Éditions Alternatives, 2006); Knut Graw, 'Beyond Expertise: Reflections on Specialist Agency and the Autonomy of the Divinatory Ritual ProcBenoess', Africa, 79, 1 (2009), 92-109; Timothy Insoll, 'Introduction: Shrines, Substances and Medicine in sub-Saharan Africa: Archaeological, Anthropological, and Historical Perspectives', Anthropology \& Medicine, 18:2 (2011), 145-66; Jonathan Roberts, 'Medical Exchange on the Gold Coast during the Seventeenth and Eighteenth Centuries', Canadian Journal of African Studies, 45, 3 (2011), 480-523. Clare Madge, 'Therapeutic Landscapes of the Jola, the Gambia, West Africa', Health \& Place, 4, 4 (2011), $293-311$. 
phytotherapeutic characteristics and active phytochemical substances, has confirmed the great ethnobotanical diversity of ecosystems, and the potential of medicinal flora and phytotherapeutical compounds. ${ }^{30}$

Although the shores of the New World and Asia have benefited from great strides made in ethnobotanical, medical, socio-historical and anthropological research, there are many gaps that need to be explored for Africa. The 'invention of tropicality', ${ }^{31}$ which tends to primarily look at modern colonialism, has neglected earlier formative periods, and conspicuous silences remain on health-related issues. The circulation of materia medica in pre- or proto-colonial situations requires an understanding of the socio-cultural dynamics of interaction between indigenous societies, and between them and incoming strangers. The present article focuses on western Africa, where the Afro-Atlantic encounter began, in order to identify interactive processes concerning healing and the curing of illnesses, and to trace their development until the late 1600s. To do this, the reciprocal dynamics of exchange of sensitive cultural information and meaning are embedded in local and regional contexts. ${ }^{32}$ The following sections, which focus on the Upper Guinea coast, most particularly on the Senegambia and the Guinea-Bissau region (GBR) as key contact zones, are based mainly on Portuguese sources, both published and archival, and of a secular and as well as a religious nature.

\section{Environments, Mobility and Cultural Exchange}

The ecology of the Upper Guinea coast or Rice Coast is characterised by low-lying, flat littoral terrain, dissected by many rivers and creeks, with abundant alluvial deposits and mangrove-lined shores - contrasting with dense woodland and savannah in the interior. High precipitation rates in coastal areas during the rainy season (from May to October), provided excellent conditions for the development of sedentary agriculture. ${ }^{33}$ The wealth of material and spiritual culture in the region testifies to the ethnic diversity of littoral areas; its complex socio-cultural mosaic is attested by several travel sources from the mid-1400s which document settlement, cultivation patterns, trade, local customs and cosmological traditions. The geomorphology and vegetation of the area south of the Gambia River feature coastal floodplains covered in mangrove swamps well suited to paddy rice cultivation, an intermediate zone with dense forest woodland, and savannah plains in the East; the GBR stands out because of the Bijagós archipelago off the coast. Elevation gradually increases from the low-lying littoral at sea level to the outliers of the Futa Jallon Mountains in a south-easterly direction. The Gambia, Casamance, Cacheu, Geba, Corubal, Pongo and Nunez rivers, and the Rio Grande inlet constitute a complex system of waterways, inter-connected by innumerous creeks, within the limits of the tidal range.

\footnotetext{
${ }^{30}$ See Abayomi Sofowora, Medical Plants and Traditional Medicine in Africa (Ibadan: John Wiley \& Sons, 1982); Bep Oliver-Bever, Medicinal Plants in Tropical West Africa (Cambridge: Cambridge University Press, 1986); Maurice M. Ewu, Handbook of African Medicinal Plants (Boca Raton, LA: CRC Press, 2014). N.H.A. Cole, 'Diversity of medicinal plants in West African habitats', in L.J.G. van der Maesen, X.M. van der Burgt and J.M. van Medenbach de Rooy (eds), The Biodiversity of African Plants (Dordrecht: Kluwer, 1996), 706-14; also Ademuragun et al., op. cit. (note 29) and Feierman and Janzen, op. cit. (note 27).

${ }^{31}$ David Arnold, Warm Climates and Western Medicine: The Emergence of Tropical Medicine, 1500-1900 (Amsterdam and Atlanta, GA: Roopi, 2003), 5.

32 John M. Janzen and Edward C. Green, 'Continuity, change and challenge in African medicine', in Selin and Shapiro, op. cit. (note 22), 1-26.

33 George E. Brooks, Landlords and Strangers: Ecology, Society and Trade in Western Africa, 1000-1630 (Boulder, CO: Westview, 1993), 19-25.
} 
Weekly markets traditionally linked various local and ethnic communities where produce, foodstuffs, commodities, remedies and information were exchanged. The expansion of the Mali Empire into the region in the 1200s brought littoral societies into contact with the Mandé, leading to a process of mandinguisation, that is the progressive assimilation of certain aspects of Mandé culture by coastal groups, and their Islamisation , and promoting the circulation of Mandé as a lingua franca. While Manding kingdoms along the Gambia River erected trade settlements, the autonomous Kaabú federation emerged, governed by non-Islamised ruling familes; its erstwhile capital, Kansalá, being located in current day Guinea Bissau. ${ }^{34}$ As morikundas [Muslim villages], such as Jabikunda and Bijine, were erected along trade routes in the Geba Valley from the thirteenth century onwards, followed by others such as Sutuko and Kassan along the Gambia River, they served as bases for traders and clerics, some pertaining to Muslim brotherhoods, to roam the intermediate and littoral zones. ${ }^{35}$ As a result, well before the arrival of Europeans, coastal regions were integrated into regional trade and religious networks connected to the Upper Niger River.

When Portuguese mariners visited the coast in the 1440s they triggered a new momentum in cross-cultural interaction. The riverine relay trade in slaves and commodities eventually led to the formation of trade settlements in the $1500 \mathrm{~s}$, populated by a mixture of free and enslaved Africans, Cape Verdean Creoles and a few Europeans. The settlement of the Cape Verde Islands (officially known as Cabo Verde since 2013) by Portuguese and Italians from 1460 onwards would establish new routes and destinations for the slave trade and the commodity trade from the mainland.

Three cross-cultural dynamics occurred in the coastal areas: an intra-African encounter between the different ethnic communities living on the coast and in the interior; a CreoleAfrican interaction, between Cape Verdean Creoles and West Africans; and a EuroAfrican encounter, that is between incoming European traders and African inhabitants. The resulting dynamics of cultural hybridisation, reinforced by clientship, wardship, pawnship (of slaves), kinship and intermarriage, existed in multiple layers against a background of regional and Atlantic commerce. ${ }^{36}$ In the case of the Senegambia and the GBR, as ethnic groups vied for control of trade routes and revenues, local trading diasporas such as the Kriston (Christianised Africans) and the laptots asserted themselves as a result of cross-cultural synergies. ${ }^{37}$ People in these highly mobile, hybrid social strata which emerged during the sixteenth century in Afro-Atlantic trade settlements on the Upper Guinea coast acted as cultural brokers (canoe men, porters, pilots, exchange agents and interpreters), mediating between incoming European and Cape Verdean traders and African societies. Creole dialects with a Portuguese lexicon developed from early contact

\footnotetext{
34 On mandinguisation, see Brooks, ibid., 59-77; 97-119; on Kaabú see Winifred Galloway, 'A History of Wuli from the Thirteenth to the Nineteenth Century' (unpublished PhD thesis: Indiana University, Bloomington, 1974); Mamadou Mané, 'Contribution à l'histoire du Kaabu, des origines au XIXe siècle', Bulletin de l'Institut Fondamentale de l'Afrique Noire (BIFAN), Dakar, 40, B, 1, (1978), 87-159; Djibril Tamsir Niané, Histoire des Mandingues de l'Ouest (Paris: Karthala/ARSAN, 1989); Carlos Lopes, Kaabunké: Espaço, Território e Poder na Guiné-Bissau, Gâmbia e Casamance pré-Coloniais (Lisbon: CNCDP, 1999).

${ }^{35}$ Cornelia Giesing and Valentin Vydrine, Ta:rikh Mandinka de Bijini (Guinée-Bissau): La Mémoire des Mandinka et des Sòoninkee du Kaabu (Leiden: Brill, 2007), 233-6.

${ }^{36}$ Walter Rodney, A History of the Upper Guinea Coast: 1545-1800 (Oxford: Clarendon Press, 1970); Jean Boulègue, Les Luso-Africains en Sénégambie (Lisbon: IICT, 1989) and Les Royaumes Wolof dans l'espace sénégambien (XIIIe-XVIIIe siècles) (Paris: Karthala, 2013).

37 Jean-Claude Nardin, 'Recherches sur les "gourmets" d'Afrique occidentale', Revue Française d'Histoire d'Outre-Mer, 53 (1966), 192-3 215-44.
} 
and settlement in the Cape Verde Islands and the GBR including the Casamance, the Kriston being its principal speakers on the mainland. ${ }^{38}$ These Afro-Atlantic lingua francas introduced a measure of standardisation of idiom and meaning, thus facilitating crosscultural translation.

In terms of published research on the anthropology and history of healing and of curing diseases in the Senegambia and GBR, Portuguese, French and English travel accounts contain relevant ethnographic data. The first administrative surveys commissioned in the early 1900 s produce preliminary data on healing traditions of different ethnic groups, but more consistent data only exists from the 1940s onwards. ${ }^{39}$ Research into the complex vernacular nomenclature of medicinal plants began in the 1950s, providing ample evidence of the multiplicity of ethnic and Creole synonyms for botanical species. ${ }^{40}$ Early accounts are, however, strongly imbued with Christian (Roman Catholic) notions, resulting in a dichotomy between (converted) Christian and Islamised or 'animist' beliefs, thereby skewing the information provided. ${ }^{41}$ In the case of the Jesuits, ... medical botany... was practised fairly consistently in virtually every missionary theatre, since it was deemed essential to the health (both financial and physical) of the missions' ${ }^{42}$ Official correspondence soon reflected upon the dangers European travellers faced when visiting tropical regions, ${ }^{43}$ and royal edicts also referred to the - fatal - diseases that afflicted African slaves, such as yaws. ${ }^{44}$

Early travel and missionary sources also make distinctions between biophysical and spiritual healing: while this in part resulted from a Christian perspective, it was also associated with the issue of competing cosmologies. By associating conversion with spiritual healing, these narratives stressed the differences between European and African traditions. As will be demonstrated below, these approaches were, however, far from

\footnotetext{
38 Philip J. Havik, 'Kriol without Creoles: rethinking Guinea's Afro-Atlantic connections (sixteenth to twentieth centuries)', in Naro et al., op. cit. (note 21), 41-74. On the Creole-speaking Kriston, see Philip J. Havik, 'Traders, Planters and Go-Betweens: The Kriston in Portuguese Guinea', Portuguese Studies Review 19, 1-2 (2011): $197-226$.

39 Octávio C. Gomes Barbosa, 'Breves Notícias dos Caracteres Étnicos dos Indígenas da Tribo Biafada', Boletim Cultural da Guiné Portuguesa, I, 2 (1946), 205-71; Amadeu Nogueira, 'Monografia sobre a Tribo Banhum', Boletim Cultural da Guiné Portuguesa, II, 8 (1947), 973-1008; António Carreira, Mandingas da Guiné Portuguesa (Bissau: CEGP, 1947) and A Vida Social dos Manjacos (Bissau: CEG, 1947); Augusto J. Santos Lima, Organização Económica e Social dos Bijagós (Bissau: CEG, 1947); José Mendes Moreira, Fulas do Gabú (Bissau: CEGP, 1948); Elmano Cunha e Costa, 'A Medicina entre os Mandingas', Portugal em África, 2, 11 (1945), 274-7; António de Almeida, 'Da Medicina Gentílica dos Bijagós', in: Conferência dos Africanistas Ocidentais, $2^{a}$ Conferência, Vol. 5 (Lisbon: Junta de Investigações Coloniais, 1952), 243-92.

40 J. do Espírito Santo, Nomes Vernáculos de algumas Plantas da Guiné Portuguesa, Estudos, Ensaios e Documentos (Lisbon: Junta de Investigações do Ultramar, 1963); M.A. Diniz et al., 'Medicinal uses of plants from Guinea Bissau', in Maesen et al., op cit. (note 30), 727-31; M.A. Diniz, et al., 'Contribuição para o Conhecimento de Plantas Medicinais da Guiné Bissau', Portugaliae Acta Biologica, 19, (2000), 417-22; L. Catarino, E. S. Martins, M. F. Pinto-Basto, M. A. Diniz 'An annotated checklist of the vascular flora of Guinea-Bissau (West Africa)', Blumea 53 (2008), 1-222.

41 José da Silva Horta, 'O Islão nos Textos Portugueses: Noroeste Africano (sécs. XV-XVII): das Representações à História, in CEAUP (ed.), O Islão na África (Oporto: Centro de Estudos Africanos, 2004), 167-181; Thiago H. Mota, 'A Missão Jesuíta de Cabo Verde e o Islamismo na Guiné (1607-16)', Temporalidades, 6, 2 (2013), $137-60$.

42 Steven J. Harris, 'Jesuit Scientific Activity in the Overseas Missions, 1540-1773', Isis, 96, 1 (2005), 71-9.

43 'Carta Régia sobre o Trato da Guiné', Lisbon, 22 February 1502; António Brásio, Monumenta Missionaria Africana, África Ocidental, $2^{\mathrm{a}}$ série, Vol. 3 (Lisbon: Agência Geral do Ultramar, 1963), 6.

44 'Carta de Perdão a João Fernandes', Lisbon, 19 May 1513, in Brásio, ibid., 59; 'Legislação da Escravatura na Guiné', Lisbon, 24 March 1514, in Brásio, ibid., 67. Yaws often confounded with syphilis, travelled with slaves to the Cape Verde islands and from there to the Americas; see Galvin, op. cit. (note 25), 77.
} 
antagonistic, illustrating the fluidity of boundaries between body and mind, and affinities between Christian, Islamic and 'animist' knowledge. Indigenous herbal remedies are often referred to with interest and appropriated for their curative properties, beneficial to both locals and outsiders. African shrines are generally dismissed as idol worship, despite the circumstance that they were consulted by both local people and foreigners for their healing powers. $^{45}$

Already during the early phase of the Afro-Atlantic encounter, outsiders were well aware of these phenomena and objects, and of their healing potential. Indeed, missionaries who were themselves actively involved in the art of healing, complained that private traders frequently sought assistance from local healers. ${ }^{46}$ The missionaries' contact with ruling families and their daily proximity to both free people and domestic slaves provided them with privileged access to local knowledge. After all, Jesuit missionaries had their own medicine chests; one of the substances they used was theriac [tyriaq; Port: teriaga/teriaca] with multiple applications. Early sources confirm that this compound, already referred to in Greek antiquity [Gr: theriake, wild beasts or poisonous reptiles], was also used in West Africa, circulating via maritime routes. ${ }^{47}$

Early travel and missionary accounts identify a number of local healing practitioners, usually in accordance with ethnic or cosmological categories. The most prominent are the itinerant Islamised healers of Manding extraction (Mandé: djararlá [healer/surgeon], and djuberlá [diviner]) called bixirins [priests; Kr: murus] in early modern sources. ${ }^{48}$ Not only did they create a following by converting Africans, they also produced amulets and talismans, just like Islamised merchants, the djilas, disseminating healing methods based on the powers of these charms. ${ }^{49}$ These objects were commonly known as sèbènw [writing] in Mandé, ${ }^{50}$ also called guarda di kurpu in Kriol, and called nóminas by Portuguese missionaries and gregories in English travel accounts. ${ }^{51}$ They come in the form of small leather pouches containing carefully folded parchments with suras or verses of the Koran, as well as symbols and geometrical patterns, activated by incantations. According to Portuguese sources, they were held in great esteem by populations in the West African region, which attributed magical powers to them: 'There are some [Wolof and Manding] bixirins ... to which the people are greatly devoted and give them a lot of credit for what

\footnotetext{
45 Valentim Fernandes, 'Descrição da Costa Ocidental da África de Senegal ao Cabo do Monte [1506]', in António Brásio, Monumenta Missionaria Africana, África Ocidental, 2ª série, Vol. 1 (Lisbon: Agência Geral do Ultramar, 1958), 730.

46 On materia medica and Jesuit missionaries, see Steven J. Harris, 'Mapping Jesuit science: the role of travel in the geography of knowledge', in John W. O'Malley et al. (eds), The Jesuits: Cultures, Sciences, and the Arts, 1540-1773, 2 vols (Toronto: University of Toronto Press, 1999/2006), 212-40; Harris, op. cit. (note 42); Timothy Walker, 'The Medicines Trade in the Portuguese Atlantic World: Acquisition and Dissemination of Healing Knowledge from Brazil (c.1580-1800)', Social History of Medicine, 26, 3 (2013), 403-31: 405.

${ }^{47}$ Gomes Eanes de Azurara, Crónica da Guiné [1453], edited by José de Bragança (Lisbon: Livraria Civilização, 1973), 367. On theriac, see Walker, op. cit. (note 46), 418.

48 André Álvares de Almada, Tratado Breve dos Rios de Guiné do Cabo Verde, Ano 1594 (Lisbon: 1654; Editorial LIAM, 1964), 21. On amulets, see Carreira, Mandingas, op. cit. (note 39), 243-5.

${ }^{49}$ Robert E. Handloff, 'Prayers, Amulets, and Charms: Health and Social Control', African Studies Review, 25, 2/3 (1982), 185-94.

${ }^{50}$ Patrick R. McNaughton, The Mande Blacksmiths: Knowledge, Power, and Art in West Africa (Bloomington, IN: Indiana University Press, 1993), 58-64. Mandé blacksmiths (M: numú) produced metal amulets.

${ }^{51}$ Richard Jobson, The Golden Trade (Amsterdam and New York: Da Capo Press, 1968), 63.
} 
they say: they make many nóminas which they give to the people, in which they have great faith and hope'. 52

Djambakós [local healers] from different 'animist' coastal groups, described as advinhadores [diviners], are also singled out for acting as '... medical doctors who visit the sick, but without taking their pulse or applying any remedies; instead they declare that the patient has been attacked by certain witches ...' ${ }^{53}$ Sources acknowledge their medical skills: ' . . . negro herbalists, [were] capable of effective and successful cures, eg. against leprosy and other diseases' ${ }^{54}$ Their importance is attributed to their responsibility for the health of indigenous chiefs and ruling families in coastal societies. ${ }^{55}$ Foliage, seeds and fruit are associated with curative medicine: Bañun healers used malagueta [chili pepper] seeds (Capsicum frutescens) for treating colds and intestinal problems, which were also used by traders and settlers. ${ }^{56}$ Fruit such as the mampataz (also known as mubura; Parinari excelsa) is mentioned without, however, indicating its common use in traditional medicine by a decoction of its bark (for a variety of purposes, including use as an abortifacient); similarly, the therapeutic use of honey and beeswax, an important export product, was also ignored. Certain fruit trees are used by the Biafada of Quínara: trees producing yellow fruit ('bigger than plums and the size of Galician lemons') called manípulos [Kr: goiaba di mato] (Euclinia longiflora) '... have medicinal properties, stopping the blood flow (anti-haemorrhagic); mixed with sugar and water, they produce a syrup ... the leaves are medicinal: boiled in water (decoction), they are used to bathe the sick' ${ }^{57}$ Nevertheless, the ambivalence of accounts comes to the fore when describing certain rituals, such as the red water ceremony, in which a (poisonous) decoction of the bark of the mancone tree (Erithrophleaum guineense) - also used as medicine - determined the veracity of witchcraft accusations, or herbal poisons used in Manding Kingdoms along the Gambia River. ${ }^{58}$ Similar doubts are expressed in relation to 'animist' shrines, for example among the Cassangas, where libations were performed with palm wine, millet beer, rum and animal blood..$^{59}$

Probably the most mentioned herbal product is the kola nut (Sterculia acuminata; Kola nitida), which triggered a lucrative Afro-Atlantic coastal trade carried on by independent traders,

particularly appreciated by 'animist' and Islamised peoples alike not only as a stimulant but also as a curative in the case of afflictions of the liver and the bladder. ${ }^{60}$ Significantly, a travel account authored by a Cape Verdean Creole merchant reveals that '... we also use it to similar effect, but the negroes put it to better use in case of headaches: they

\footnotetext{
52 Jobson, ibid., 21, and Almada, op. cit. (note 48), 47. See Kedzierska et Jouvelet, op. cit. (note 29), on talismans and power objects (M: basi): 12, 28, 48; on incantations: (M:kilisi), 12, 21, 70/1; and on Mandé herbalists and djiridon (M: science of the trees), 64-79.

53 Jobson, op. cit. (note 51), 21.

54 Ibid., 21.

55 Ibid., 8/9.

56 Almada, op. cit. (note 48), 84.

${ }^{57}$ Ibid., 109.

58 Ibid., 45; 65/6.

${ }^{59}$ Ibid., 68/9. On spirit shrines, see Eve Crowley, 'Regional Spirit Shrines and Ethnic Relations in GuineaBissau', in: Africana Journal, XVII (1998), 27-39; Robert Baum, Shrines of the Slave Trade: Diola Religion and Society in Precolonial Senegambia (New York: Oxford University Press, 1999); Rosalind Shaw, Memories of the Slave Trade: Ritual and the Historical Imagination in Sierra Leone (Chicago, IL, and London: Chicago University Press, 2002).

60 Jobson, op. cit. (note 51), 134; Almada, op. cit. (note 48), 56.
} 
chew it and apply the decoction to their temples' ${ }^{61}$ Another commodity, cloves (Syzygium aromaticum), renowned for its medicinal properties, was also in great demand among Africans, suggesting its early introduction on the coast from the Portuguese East Indies. ${ }^{62}$

\section{Afro-Atlantic Interaction and Settlement}

The coastal and riverine ports which gradually emerged during the second half of the $1500 \mathrm{~s}$ and early 1600s in the Senegambia and the GBR were to become important sites for AfroAtlantic trade and cross-cultural exchange. The locations also facilitated the exchange of diseases, medical knowledge and therapeutic substances in West Africa, as populations underwent processes of acculturation. Ports such as Geba, São Filipe, Cacheu and Santa Cruz de Biguba, some of which were fortified, and many other smaller sites altered AfroAtlantic relations in the region, and were inter-linked with Senegambian posts such as Rufisque, Joal and Portudal. Kriston communities settling along the region's rivers and creeks were to thrive there in subsequent centuries, weaving itinerant trade networks while retaining their autonomy until the early 1900s. These early modern tabankas [villages or stockades] were not only erected by interlopers (private traders) but also by African ruling families, such as the Bañun ports of Buguendo, Bichangor and Brikama. Set in marshlands, some were described as 'unhealthy', ${ }^{63}$ prompting traders to move to more salubrious locations.

The town of Cacheu, founded in the mid-1500s, would become the main Portuguese trading post on the Upper Guinea coast from the early 1600s. It was the site of the first missionary hospice indicating local demand for medical assistance. ${ }^{64}$ Evidence from the coast and the Cape Verde islands also shows that the latter maintained liaisons with African and Creole women on account of their cultural competence for healing and curing, a configuration which was reproduced on the coast by independent traders ${ }^{65}$ Ill-suited diets and alcohol abuse are often referred to as serious health threats for Europeans in the tropics, causing their early demise while endangering the lives of others. ${ }^{66}$ In this respect, the question of concubinage and marriage between Atlantic traders and African women was particularly relevant. Talking about the port of Kassan on the Gambia River a Portuguese trader stated that '.. all the time (three years) that I lived there, I never caught any fevers, which in these remote parts is by no means a minor feat' ${ }^{67}$ During his residence in Cacheu, he employed a lavandeira [washer-woman], ${ }^{68}$ a euphemism for a local female companion, who no doubt provided much needed health care or accessed healing networks in the area. For those involved in these exchange networks, access to local preventative and curative knowledge by means of concubinage with free or slave women was essential for survival. ${ }^{69}$

61 Almada, Ibid., 56.

62 The oil extracted from flower buds has anaesthetic, antiseptic, febrifuge and anti-malarial properties.

63 Almada, op. cit. (note 48), 77.

${ }^{64}$ Carta de Frei Cipriano ao Bispo de Cabo Verde, Cacheu, 10 June 1596, in Brásio, op. cit. (note 43), 392.

${ }^{65}$ Francesco Carletti, Reis Om De Wereld [1594-1606] (The Hague: Kruseman, 1965), 19; Jobson, op. cit. (note 51), 28-33.

66 Jobson, op. cit. (note 51), 40-2.

${ }^{67}$ Francisco de Lemos Coelho, in Damião Peres (ed.), Duas Descrições Seiscentistas da Guiné (Lisbon: Academia Portuguesa de História, 1990), 122.

68 Ibid., 147.

${ }^{69}$ Nathalie Reyss, 'La Santé à St. Louis du Sénégal à l'époque pré-coloniale d'auprès des récits de voyages et des romans: Alimentation, hygiène et santé, ou, Le Métissage comme moyen de survie' (unpublished MA thesis: Sorbonne I, Paris, 1981). 
Written evidence abounds in the 1600s on the existence of widespread networks of interlopers - the so called lançados and tangomãos - living and trading directly with Africans along the coast and rivers from Senegal to Sierra Leone. Their close relations with 'animist' and Islamised African dignitaries were regarded suspiciously by the Crown, the Catholic Church and the Inquisition. Nevertheless, these traders, many of whom had Cape Verdean and Sephardi roots, were key informants for chroniclers, incoming strangers and also for African dignitaries. ${ }^{70}$ Having undergone rites of passage, they had acquired cultural and therapeutic knowledge. Travel accounts refer to the use of herbal remedies and poisons (eg. for hunting) in their areas of settlement: an early seventeenth-century source lists twenty-three plants with their vernacular names and their phytotherapeutic properties. ${ }^{71}$ The data contains explicit as well as hidden references to their medicinal aspects. For example palm trees (Elaeis guineensis) are referred to, their chabéu [palm oil] being used for cooking and as a mezinho [popular cure] ${ }^{72}$ but the leaves, roots, bark and fruit of the tree are still used for a great variety of pathologies with purgative, diuretic (leaves); as a vermifuge and as an antidote to snake and insect bites (oil); as a febrifuge, to treat arthritis and rheumatism; and as a painkiller (root). ${ }^{73}$ The species listed range from fruit trees, such as kola, to small herbaceous plants, such as malagueta. In the case of malagueta (Capsicum frutenscens) he describes its phytotherapeutic use, for example, for the treatment of stomach and intestinal pains; kola nuts had purgative properties and mamboi leaves (Dialium guineense or Bridelio micrantha) cured headaches. ${ }^{74}$ In addition, reference is made to the copal tree (eg. Copaifera guibourtiana) ${ }^{75}$ growing in the West African savannah zone, which produces an amber-coloured resin, well-known in Latin America; the oil and decoctions of leaves and bark are used to treat skin complaints, wounds and snake bites.

The phytotherapeutic applications given are by no means random, given that the health conditions in question were common among coastal peoples and trading communities alike. Indeed, the species are well chosen, as they all possess therapeutic properties. Some are of particular relevance such as veludo (Dialum guineense) commonly used as an analgesic, an anti-malarial treatment, an anti-diarrhetic diuretic, and used to treat eye and parasitic infections, and manganaz (Icacina oloviformis) as a febrifuge, an analgesic abortifacient, and for treating animal and insect bites, eye infections, impotence and skin complaints. The fruit of the kola tree, which was one of the main trading commodities along the coast, is still widely used for ceremonial purposes. ${ }^{76}$ Besides being a stimulant containing caffeine and theobromine, it was also used to combat depression and neurasthenia, and the oil extracted from the seeds/nuts was used as an analgesic, an antidiarrhetic and an anti-rheumatoid treatment. In trade settlements such as Geba, a mixture

\footnotetext{
${ }^{70}$ André Donelha, Descrição da Serra Leoa e dos Rios de Guiné do Cabo Verde, in Paul E. H. Hair and Avelino Teixeira da Mota (eds), (Lisbon: Junta de Investigações Científicas do Ultramar, 1977), 108, 144, 148, 162, 166-170: 176.

${ }^{71}$ Ibid., 82-8.

72 Ibid., 80.

${ }^{73}$ Philip J. Havik, “"Veneráveis Representantes da Vegetação Tropical”: Médicos, Curandeiros e Fitoterapias na Guiné-Portuguesa (Sécs. XIX-XX)', in Actas do Workshop Internacional Plantas Medicinais e Práticas Fitoterapêuticos nos Trópicos (Lisbon: IICT, 2009).

${ }^{74}$ Donelha, op. cit. (note 70).

${ }^{75}$ Ibid., 218-20.

${ }^{76}$ Brooks, op. cit. (note 33), 79-95.
} 
of the oil with red wine and egg-yolk was also applied in case of respiratory afflictions, including bronchitis. ${ }^{77}$

The widespread use of talismans referred to above, made and sold by Mandé healers and diviners and worn by West Africans around their foreheads and necks, or tied with leather straps round their body and arms, is a constant reminder of hybridised forms of healing. ${ }^{78}$ Their usage denotes an ongoing regional symbiosis in terms of the understanding of misfortune and illness, as well as in the treatment of hot and cold diseases. ${ }^{79}$ The combination of koranic scriptures with magical powers was reminiscent of the use by Catholic clergy of popular religious objects such as crucifixes and rosaries and notions in the conversion of non-Christians. The pouches were - and still are - applied to the part(s) of the body affected by illness or ailment, but also used for preventive purposes, to protect against forms of witchcraft, accidents, wounds or illness. They circulated in coastal trading ports, but also found their way into Europe, the Atlantic and the Americas, following the trail of the trading and African diasporas. ${ }^{80}$

References to the talismans increase in the course of the 1600 s, above all as a result of the presence of Catholic missionaries on the coast and the incursions of the Portuguese and Spanish Inquisition, revealing their use by non-Africans. Indeed, merchant traders also mentioned the nóminas in association with the presence of bixirins among the Islamised Wolof and Manding, without, however, denouncing their use. ${ }^{81}$ The dissemination of Mandé/Manding talismans in the Senegambia and GBR formed an integral part of the process mandinguisation of groups such as the Jola or Biafada, falling under Mandé influence or control. At the same time, fetishes in simple leather pouches or decorated with multi-coloured glass beads imported from Europe were worn by ' . . Catholic Portuguese, Sephardi, Muslims and idolatrous ...' residents of coastal ports like Rufisque on the Petite Côte of Senegal. ${ }^{82}$ Along the coast of Sierra Leone, '.... the whites [interloper tradersettlers] worshipped god and the blacks the devil ...', but they all wore fetishes. ${ }^{83}$

Much appreciated by Islamised groups and used as a token of respect and gift-giving, and also for divination, kola nuts are repeatedly mentioned with regard to their medicinal properties: '. . . the Mandinga negroes have great faith in this bitter fruit ... being the main mezinha [mesiñu in Guinean and Cape Verdean Creole], that they have, using it to treat all ailments, and above all ... relieves them of their sins, by simply chewing

${ }^{77}$ Havik, op. cit. (note 73), 11-3. On Geba see, Philip J. Havik, 'The Port of Geba: At the Crossroads of AfroAtlantic Trade and Culture', Mansa Studies, 9 (2007), 21-50.

78 Jobson, op. cit. (note 51), 69; 75/6, and Donelha, op. cit. (note 70), 148, for the encounter in the Gambia with Gaspar Vaz, a Kriston and former slave, who wore a long white tunic or bubú with talismans but professed to be a Christian.

79 António Carreira, 'Símbolos, Ritualistas e Ritualismos na Guiné Portuguesa', Boletim Cultural da Guiné Portuguesa, XVI, 63 (1961), 505-39. The centre of Mandé religious teaching in the region, Bijine (near Bafatá) was once a Nalú settlement; see also Giesing and Vidryne, op. cit. (note 35). The origin of Mandé nyantchó or ruling families are associated with the Bañun; Mané, op. cit. (note 34), 109-11.

${ }^{80}$ Jobson, op. cit. (note 51), 50-1 on the Gambia; for the Atlantic, see James Sweet, Domingos Alvares, African Healing, and the Intellectual History of the Atlantic World (Chapel Hill, NC: University of North Carolina Press, 2011). On Mandé amulets or boliw, see Agnes Kedzierska Manzon, 'Humans and Things: Mande Fetishes as Subjects', Anthropological Quarterly, 86, 4 (2013), 1119-52.

${ }^{81}$ Coelho, op. cit. (note 67), 107/8. Traders gave or sold parchment paper to Islamised healers and diviners for the making of talismans; Prosper Cultru (ed.), Premier voyage du Sieur La Courbe fait en Afrique en 1685 (Paris: Édouard Champion and Émile Larose, 1912), 72.

${ }^{82}$ Nicholas Villault, Sieur de Bellefond, Relation des Costes d'Afrique appelées Guinée (Paris: Denis Thierry, 1669), 55/6: 70: 83 .

83 Ibid., 112. 
on them ...' ${ }^{84}$ Biafada ruling lineages regularly consulted the Islamised healers who visited their territory, giving them talismans. ${ }^{85}$ Indeed, the Biafada who were regarded as 'great herbalists' and 'very good friends of the white men', acted as go-betweens with the Nalú further south, where kola trees were common, re-selling them to their Manding and Atlantic clients. ${ }^{86}$ The Nalú, in whose territory an important shrine was located, were described as 'great witches ${ }^{\prime 87}$, much sought after for their healing powers; indeed, a Catholic mission established a hospice among the Nalú in the mid-1600s. ${ }^{88}$ By the 1600s the Fulbe of the Futa-Djallon (currently Guinea Conakry) region were regarded as great herbalists, and thought to have the best antidotes or contra-ervas against wounds and illnesses; indeed, '. . all the whites stock them'. ${ }^{89}$ There was a lively trade in the Rio Nunez area, (currently Guinea Conakry) ${ }^{90}$ in indigo, widely used as a dye for cotton cloth (eg. by the Mandé-speaking Saracollé), but also associated with its medicinal properties: skin complaints were treated with an infusion made of the leaves of Indigofera suffruticosa. The locust bean tree or Parkia biglobosa, besides much appreciated for the sweet pulp of its fruit, was another multipurpose medicinal species, widely used to treat malaria.

Tobacco leaves are also mentioned in connection with trade and healing: travel accounts state that the best tobacco is found in the Góbia region, on the South bank of the Rio Grande, which is no coincidence: tobacco leaves were not only used as exchange goods, but were also known for their multiple medicinal properties. For example, for the treatment of mosquito and snake bites, as well as being an anti-sceptic, a painkiller and an antirheumatoid drug, while also being effective against stomach disorders. ${ }^{91}$ The Columbian exchange was particularly visible in the dissemination of venereal diseases throughout the West African region above all in trading posts and settlements. It affected the Portuguese and Cape Verdean trading communities, which had their own local healers to treat them, possibly taking recourse to infusions of the leaves of the baobab tree (Adansonia digitata) common in the area. ${ }^{92}$ Thus, by the mid-1600s, New-World products and therapies had been adopted by local communities on the Guinea coast, whilst other local African techniques and substances had found their way into the Atlantic by means of exchange networks linking the African interior to coastal regions, and the latter with the Atlantic region.

\section{Competing and Complementary Cosmologies}

Early missionary activity on the mainland was to introduce a change of perspective regarding local beliefs and practices from the early 1600s, above all with the arrival

\footnotetext{
${ }^{84}$ Coelho, op. cit. (note 67), 158.

85 Almada, op. cit. (note 48), 97-9.

${ }^{86}$ Brooks, op. cit. (note 33), 80-7. Kola nuts introduced insects that damaged the wooden ships; leaves from the Cabopa tree (Mitragyna stipulosa) - also an anesthetic and anti-malarial - were used to deter them.

87 Almada, op. cit. (note 48), 113.

${ }^{88}$ Coelho, op. cit. (note 67), 206/7. For Nalú healing traditions, see Amélia Frazão-Moreira, Plantas e Pecadores: Percepções da Natureza em África (Lisbon: Livros Horizonte, 2009).

${ }^{89}$ Coelho, op. cit. (note 67), 208; on Fula phytotherapy, Moreira, op. cit. (note 39), 244-7; E.T. Gomes and M.A. Diniz, 'Plantas Usadas em Medicina Tradicional na Região de Contuboel', Comunicações, Série de Ciências Agrárias (Lisbon: IICT, 1993), 153-65.

90 Almada, op. cit. (note 48), 114; Coelho, op. cit. (note 67), 209.

${ }^{91}$ Coelho, op. cit. (note 67), 192.

92 Cultru, op. cit. (note 81), 263.
} 
of the Jesuit mission on the Cape Verde islands. Focusing on the conversion of coastal peoples and the counter-offensive against Islamisation, missionaries were, however, rather ambivalent about the occult aspects of African healing: whilst respectful of local herbal remedies, they often dismissed healing practices as pagan rites, sorcery or witchcraft. In the case of the Cape Verde islands, they lamented the presence of healers originating from the Coast who, though converted, still continued '... to carry out divination and cures with remedies which they had learnt in Satan's school. . . on the estates of the islands'. ${ }^{93}$ Activities of these healers on the continent also figured in the mission's diatribes against the 'great superstitions' to which African peoples were prone. 'All kinds of illnesses and accidents that affected a given person are attributed to someone who bore a grudge against them, and if the spell continues they believe that they, their enemies, will eat (that is, kill) them'. ${ }^{94}$ Thus, the conversion of Manuel Cubé, a master of ceremonies and diviner among the Bullom in Sierra Leone into a 'soldier of Christ' by Jesuit missionaries was hailed as a grand victory. ${ }^{95}$ There are indications, however, that these miraculous conversions in fact amounted to a deliberate strategy by local actors in order to borrow the healing powers attributed to priests and increase their healing skills and prestige. ${ }^{96}$ Kriston travelling in the African interior and between the coast and the Cape Verde islands were also accused of similar practices. ${ }^{97}$

Local healers and diviners were said to be the 'masters of this diabolical art'. Missionaries extracted information about their practices by hearing confessions of converted patients who confirmed that these healers often succeeded in curing the sick. ${ }^{98}$ In some cases, divinatory animal sacrifices carried out to determine the causes and origins of spells and witchcraft are described in detail. ${ }^{99}$ Indeed, their reports associate healing with conversion, suggesting that missionaries were widely regarded as preachers and healers, and even as witches. At the same time, missionaries occasionally reported the sighting of apparitions and ghosts, while associating snakes with witchcraft. ${ }^{100}$ Although they extensively indulged in praise of miracles in order to promote conversion ${ }^{101}$ using healing as a tool, missionaries systematically insisted on the removal of competing pagan shrines. Centring their efforts on ruling families was a well-studied formula in order to gain an African following. ${ }^{102}$ Despite having once believed in the mezinhas upon falling ill, one of these converted 'kings' was said to have refused the services of his former personal

\footnotetext{
93 Fernão Guerreiro, Relação Anual que fizeram os Padres da Companhia de Jesus nas suas Missões [... ] dos Anos 1600-9, Artur Viegas (ed.), Vol. 3 of 3 (Coimbra: Imprensa da Universidade, 1931), 281.

94 Baltasar Barreira, 'Carta Annual', 1 July 1611, in António Brásio, Monumenta Missionaria Africana, África Ocidental, $2^{\text {a }}$ série, Vol. 4 (Lisbon: Agência Geral do Ultramar, 1968), 463.

95 Guerreiro, op. cit. (note 93), 254.

96 Baltasar Barreira, 'Carta ao Rei Filipe II', Biguba, 13 May 1607, in: Brásio, op. cit. (note 94), 260.

97 On Kriston of Biafada origin, baptised in the Cape Verde Islands who kept 'animist' shrines,see António Brásio, 'Padre António Vieira e as Missões de Cabo Verde', in: António Brásio, História e Missiologia: Inéditos e Esparsos (Luanda: Instituto de Investigação Cientifica de Angola, 1971), 726-34: 731.

98 Baltasar Barreira, in Brásio, op. cit. (note 94), 464.

${ }_{99}$ Manuel Álvares, 'Etiopia Menor e Descripção Geográfica da Província de Serra Leoa', manuscript (Lisbon, Convento de São Francisco, approx. 1616), L(eaf) 9 and transcription by Avelino Teixeira da Mota and Luís de Matos, trans. Paul E.H. Hair (Liverpool: University of Liverpool, Department of History, 1990).

100 Guerreiro, op. cit. (note 93), 246, 269.

${ }^{101}$ Missionaries conducted exorcisms on African soil to cure 'bewitched' Africans; see Guerreiro, op. cit. (note 93), 282.

102 For 'miraculous' cure of an interloper, by a Jesuit 'spiritual doctor' in Sierra Leone, see Guerreiro, op. cit. (note 93), 275.
} 
healer. ${ }^{103}$ Chapels, crosses and images depicting Christ or the Virgin Mary were meant to replace local idols, but were regarded locally as Christian chinas dos cristãos [shrines]. ${ }^{104}$ The converted were said to have great faith in sacred Christian relics to the point of using them as talismans to ward off danger and illness, decorating them with animal skulls and performing libations with the animal blood and alcoholic spirits. ${ }^{105}$ Among the Bañun, Catholic priests were also called the 'marabouts of the Christians'. ${ }^{106}$ Thus a symbolic continuum emerges between 'pagan', and 'Christian' practices, artefacts and symbols. Even though 'animist' shrines and the talismans or nóminas made by Islamised clerics are portrayed as an impediment to Christian conversion, ${ }^{107}$ some Europeans did believe these 'perverse pilgrims' worked miracles, such as making rain. ${ }^{108}$

Missionary sources also focus on local plant species such as Cassia sieberana (Kr: kana fistra) - with analgesic properties - and, once again, malagueta, as well as kola, from which important herbal remedies were extracted, but they do not refer to their medicinal usage. ${ }^{109}$ A Portuguese interloper established in Sierra Leone informed the Crown that a Jesuit missionary was taking specimens of kola nuts along to Lisbon, adding they were highly appreciated by the local population as a stimulant and a preventive drug. ${ }^{10}$ Correspondence confirms priests' succumbing to malarial fevers; one of them was treated on the Cape Verde islands by prayer, 'divine cures' and above all bloodletting, a humoral method used with great frequency. ${ }^{111}$ Although one may speculate whether in certain cases local herbal remedies were applied, Jesuit missionaries stated that they ' ... could not use the favourite means employed by the secular population to preserve their health'. ${ }^{112}$

Little attention has so far been given to this fundamental aspect of the permanence of officials and missionaries on the Coast. ${ }^{113}$ It is known that the Jesuit missionaries in Cape Verde tended vegetable gardens - as they did in Europe - because they are mentioned in the list of assets purchased and pertaining to the Order on the island of Santiago, growing medicinal plants and herbs. ${ }^{114}$ The list of goods imported from Europe show that some usage other than gastronomical might have been made of ginger-root (Zingiber officinalis)

\footnotetext{
103 Guerreiro, op. cit. (note 93), 268.

104 Baltasar Barreira, 'Relação das Coisas da Guiné', May 1607, in Brásio, op. cit. (note 94), $271-7$.

105 Baltasar Barreira, in Brásio, op. cit. (note 94), 272, 451.

106 Mateo Anguiano, Misiones Capuchinas en África: Misiones al Reino de la Zinga, Benin, Arda, Guinea e Siera Leona, Vol. 2 (Madrid: Instituto Santo Turibio de Mogrovejo, 1957), 269.

${ }^{107}$ Letter of Baltasar Barreira to João Álvares, 1 August 1606, in Brásio, op. cit. (note 94), 166; Baltasar Barreira, 'Carta Anual, 1610-11', 17 July 1611, in Brásio, op. cit. (note 94), 442; Letter of Manuel Álvares, approx. 1615, in Nuno da Silva Gonçalves (ed.), Os Jesuítas e a Missão de Cabo Verde, 1604-42 (Lisbon: Brotéria, 1996), 336. 108 For eye-witness account, see Álvares, op. cit. (note 99), L. 10.

${ }^{109}$ For more background information, see Carreira, Mandingas, op. cit. (note 39), 241 and Diniz, et al., 'Contribuição' op. cit. (note 40), 421.

${ }^{110}$ Letter of Sebastião Fernandez Casão to Rei Filipe II, Biguba, 20 April 1607, in Brásio, op. cit. (note 94), 246.

${ }^{111}$ Letter of Padre Manuel de Almeida, 12 August 1607; in Brásio, op. cit. (note 94), 284; Avelino Teixeira da Mota (ed.), As Viagens de D. Frei Vitoriano Portuense a Guiné e a Cristianização dos Reis de Bissau (Lisbon: Junta de Investigações Científicas do Ultramar, 1974), 76; Anguiano, op. cit. (note 106), 117; Cultru, op. cit. (note 81), 229/30.

112 Guerreiro, op. cit. (note 93), 239.

113 On their diets, Gonçalves, op. cit. (note 107), 169. For a critical assessment, see Carlos Almeida, 'Uma Contribuição para o Estudo da Presença da Companhia de Jesus em Cabo Verde (1604-42)', Kultura, 2 (1998), $222 / 3$.

114 Gonçalves, op. cit. (note 107), 216; 'Rol dos Bens dos Padres Jesuítas em Santiago de Cabo Verde', 10 March 1627, in Brásio, Monumenta Missionaria Africana, África Ocidental, 2ª série, Vol. 5 (Lisbon: Academia Portuguesa da História, 1989), 170-3.
} 
and cloves, ${ }^{115}$, widely used at the time for medicinal purposes ever since sea-based trading routes had been established with the Orient in the early $1500 \mathrm{~s} .{ }^{116}$ In the Portuguese settlements on the coast, officials were well aware of local therapies for common ailments such as malaria; for example, the governor of Cacheu offered his services to provide his French guest with an 'admirable remedy' against malarial fevers. ${ }^{117}$

However, little information is forthcoming on the use of European medicine on the Guinea coast, where the mission only had one firm base, that is in the small hospice of Santo António in Cacheu, erected by Capuchin missionaries in the late 1500s. Their writings regularly mention species such as kola trees and malagueta in connection with the commercial profits that could be made, ${ }^{118}$ but also discuss their phytotherapeutic properties. As long stays on the Coast resulted in a high mortality rate, the head of the mission used the Cape Verde islands as a temporary and intermittent base for clerics to acclimatise. ${ }^{119}$ A well-irrigated nursery with banana, fig, orange and palm trees and a great variety of vegetables guaranteed a healthy diet. The importance of crops sold in the town of Cacheu - where clerics were based - and surrounding ports stress the importance of agriculture and fresh staple foodstuffs such as rice and maize for the coastal trade. The fertility of the land and the farming expertise of its inhabitants were frequently mentioned in missionary reports, indicating familiarity with indigenous ethnobotanical knowledge. ${ }^{120}$ For example, the many uses of the palm tree are enumerated: the chabéu extracted from them was not only used for cooking and lighting, but also for ointments made from the kernels.

While the Bañun were described as 'excellent farmers', they also received praise for their preparation of 'magic medicines' made from certain herbs, and for their capacity to increase their efficacy. ${ }^{121}$ These 'expert herbalists' were regarded on a par with modern doctors: sufficiently knowledgeable to perform surgical operations. The Jesuit mission had spent considerable time with the Bañun, renowned for their healing skills, converting members of ruling families, building chapels in their riverine ports and using effigies of the Virgin Mary to work miracles. ${ }^{122}$ Some of their herbal cures, such as the treatment of flesh wounds, were therefore of great importance to the mission. ${ }^{123}$ Although local panacea such as the consultation of Bañun chinas [Bañun: hatichira, 'animist' shrines] prompted clerics to condemn their methods as superstitious trickery, ${ }^{124}$ missionaries were clearly locked in a complex and controversial dialogue with locals' healing powers on account of their own fragile state of health.

\section{Healing, Magic and Witchcraft}

Denunciations made to the Lisbon Inquisition, which was established in 1536 and exercised jurisdiction over Portugal's overseas possessions, reflected missionary discourse

\footnotetext{
115 Gonçalves, op. cit. (note 107), 321.

116 On use of ginger and cloves, and theriac, see Walker, op cit. (note 46), 413, 418.

117 Cultru, op. cit. (note 81), 232/3.

118 See 'Descrição da Serra Leoa e proposta para tornar o território colónia da Coroa [approx. 1611]', in Gonçalves, op. cit. (note 107), 307/8.

119 Baltasar Barreira, 'Carta Anual', 17 July 1611, in Brásio, op. cit. (note 94), 455.

120 Álvares, op. cit. (note 99), L. 19.

121 Ibid., L. 27.

122 Ibid., L. 23.

123 Ibid., L. 27.

${ }^{124}$ Ibid., L. 27v.
} 
whilst also producing a shift in emphasis as a result of the modus operandi of persecution rather than conversion. ${ }^{125}$ The notable increase in inquisitorial activity on the coast coincided with the arrival of missionaries pertaining to the Franciscan order. Replacing the Jesuits, they collaborated with the Lisbon Inquisition, while Spanish Capuchin missionaries also detailed deviant local customs and sorcery. Denunciations and trials with regard to 'ritos Africanos' [African rites] and 'feitiçaria' [witchcraft] brought local healing practices into focus. Missionaries working with the Portuguese and Spanish Inquisitions denounced the 'diabolical error' deeply ingrained in local communities' worldview with the help of 'sorcerers' that witchcraft was the main reason for people's untimely demise. ${ }^{126}$ Although the main targets of the Inquisition's activities were Sephardi interlopers branded as New Christians [Cristãos Novos in Portugal, or conversos in Spain] and their 'judaising' tendencies, witchcraft accusations were mainly directed at converted or baptised Africans. ${ }^{127}$

Most denunciations regarding witchcraft were associated with Guinea, Cape Verde and Angola, involving inhabitants of (often fortified) trading towns governed by military officials appointed by the Portuguese Crown. In the Guinean case, the large majority of denunciations centred on the town of Cacheu, where the first capitão-mor [governor] took office in 1615. Other locations were the ports of Buguendo, Bichangor and Guinguim, and Farim on the Cacheu River, as well as the ports of Ale and Joala on the Petite Côte (Senegal), and Ziguinchor on the Casamance River, north of Cacheu. Over a period of almost two centuries from 1536 to 1700 , a total of 54 denunciations of witchcraft and 46 cases of pursuing African rites were registered, most occurring during the 1600 s, the majority of which related to free Christianised women from Guinea and Cape Verde. ${ }^{128}$ In them Afro-Atlantic trade settlements emerge as healing communities which benefited from tranfers of cultural knowledge on health and illness. ${ }^{129}$

Although most denunciations refer to local healing practices, some focus on strangers, such as an individual from Malacca, who had settled 'among the negroes', that is the Bañun, in the early 1600s. He wore a long white bubú as worn by Muslim clerics, and a large number of nóminas around his neck and on his forehead '. . . just like the heathen'. ${ }^{130}$ Having been sighted in the residence of the Bañun djagras [Bañun: udjagar] or the chiefs of the ruling family in the ports of Bichangor and Buguendo favoured by interlopers, they questioned him on whether he was a Christian. He allegedly answered that he '... scorned Christians, and accompanied negroes in order to make their shrines ...' while adding that he acted as a healer and also accompanied them in battle. ${ }^{131}$ Although no information is provided on his methods, it is likely that he was sought after by local dignitaries for

\footnotetext{
125 On the Portuguese Inquisition and Africa, see Francisco Bethencourt and Philip J. Havik (eds), Revista Lusófona de Ciência das Religiões, III, 5/6 (2004), 21-173.

126 Anguiano, op. cit. (note 106), 131.

${ }^{127}$ For an overview of the Portuguese Inquisition's intervention in Africa, see Filipa Ribeiro da Silva, 'A Inquisição em Cabo Verde, Guiné e São Tomé e Principe (1536-1821): Contributo para o Estudo da Política do Santo Ofício nos Territórios Africanos' (unpublished MA thesis, 2 vols: New University of Lisbon (UNL), 2002).

128 Ibid., Vol. 1, 156-9.

${ }^{129}$ Philip J. Havik, 'La Sorcellerie, l'acculturation, et le genre: La Persécution réligieuse de l'inquisition portugaise contre les femmes africaines converties en Haut Guinée (XVII ${ }^{\mathrm{e}}$ siècle)', Revista Lusófona de Ciência das Religiões, III, 5/6 (2004), 99-116.

${ }^{130}$ Duarte Lopes Rosa, 'Denúncia contra Manuel da Silva Índio', Livro de Denúncias 205, Lisbon, 22 September 1618 (Inquisição de Lisboa, Instituto de Arquivos do Torre do Tombo (IANTT)).

131 Ibid.
} 
his Oriental healing skills, combining them with African practices. Imprisoned on the island of the Cape Verdean island of Santiago, he apparently fled to Angola, where he may have carried on his consultations. Another denunciation detailed the statements made by a Portuguese trader frequenting Cacheu as well as Bichangor who wanted to become a witch. Resident on the coast, he had learned the tricks of the trade from a local woman familiar with the 'trato com o demónio [dealings with the devil] although he failed to conclude a satanic pact. ${ }^{132}$

Coastal towns such as Cacheu, established as an Afro-Atlantic settlement in the 1500s, were sites of intensive trade from which thousands of slaves - as well as ivory, beeswax and hides - were exported annually to Cape Verde and the Americas, in exchange for iron bars, rum, cotton cloth, gunpowder, firearms, swords and trinkets. ${ }^{133}$ The port was Portugal's main foothold in the region and counted approximately 3000 inhabitants in the mid-seventeenth century, including domestic slaves. The population of these ports was a curious mixture of a small number of European and Cape Verdean traders, and an overwhelming majority of Christianised Africans, the Kriston, as well as domestic slaves. It was divided into two wards, the 'Cold' and the 'Hot Town': the former comprising the fort with its mud walls and the tabanka, while the latter included the area beyond the Santo António convent, and housed the free Kriston population as well as the funku [slave houses]. While reports indicate that clergy took care of the spiritual needs of the residents of the Cold Town, mainly traders and officials, the free people living in the Hot Town employed in the riverine and coastal relay trade were said to live 'in limbo', that is half-way between pious civilisation and outright savagery. But European traders also kept residences in the Hot Town, while the Kriston and domestic slaves worked in the Cold Town. ${ }^{134}$ The Catholic hospice's strategic location on the frontier between the two Cacheu neighbourhoods suggests a measure of mediation exercised by the missionaries residing there.

'Hot town' residents were depicted by Jesuit missionaries as caring settlers, endowed with 'profound sentiments of piety'. Sailors and other crew from the ships that passed were lodged and nursed back to health in residents' 'casas de misericórdia' [alms-houses] after long and disease-ridden voyages. ${ }^{135}$ Once visitors had recovered, they were provided with sustenance and treated before embarking upon their next voyage. In fact, the choice of location was associated with the 'healthier airs' of Cacheu, which was commonly used for the convalescence of the sick in the region. ${ }^{136}$ In this respect, a Jesuit cleric reinforced his argument by, significantly, evoking the charitable attitude of a female inhabitant of the town towards one of his colleagues in need. ${ }^{137}$ Jesuit sources are characteristically ambivalent but sympathetically inclined towards the town, which they had made their base, whereas documents produced by their successors of the Franciscan Order tend to be much

\footnotetext{
132 António Dias and António de Crasto, 'Denúncia contra Bartolomeu Rodrigues Baesa', Cacheu, 4 April 1630, Livro de Denúncias 222 (Inquisição de Lisboa, IANTT).

133 Brooks, op. cit. (note 33), 226-44.

134 Álvares, op. cit. (note 99), L. 14/14v; Coelho, op. cit. (note 67), 148.

135 For medical assistance on Portuguese caravels, see Aníbal de Castro, 'Físicos, Cirurgiões e Boticários nas Naus dos Descobrimentos', Arquipélago-História, $2^{\mathrm{a}}$ série, IV, 2 (2000), 535-50, 538.

136 Jean Barbot, Letter 13, 1688, in Paul E.H. Hair, Barbot on Guinea: The Writings of Jean Barbot on West Africa, 1678-1712 (London: The Hakluyt Society, 1992), 162.

137 Álvares, op. cit. (note 99), L. 19v.
} 
more critical of deviant practices, as were Spanish clerics from the Capuchin Order with close ties to the Spanish Inquisition. ${ }^{138}$

One of the most visible, tell-tale signs of cultural borrowing were religious objects. Just like local shrines, amulets and talismans, Christian artefacts such as crosses, rosaries, effigies and images - as well as ritual sacred oils used for anointing and healing purposes - were apparently held in great esteem by the local population. The distribution of gold crucifixes among the 'negroes and infidels' by a Portuguese trader impersonating an Inquisition official in the Cacheu served as an example. ${ }^{139}$ The use of religious symbols not only bolstered the status of the outsider in question, but also worked to the advantage of Africans displaying such insignia; the Kriston traditionally wore (and still wear) necklaces with crosses. In an Inquisition trial against interlopers who were accused of committing blasphemous acts in the Bañun town of Buguendo, ${ }^{140}$ witnesses also mentioned the 'sale of crucifixes to negroes' by a mestizo trader and even the ' . . . theft of an altar in the town of São Domingos (on the Cacheu River) by negroes ... '. ${ }^{141}$ Regular mention is made of the gift-giving of religious artefacts, such as images of Christ and the Virgin Mary, by Catholic ministers and their usage by local communities and by lay 'indigenous [Christian] priests' in 'pagan rituals'. 142

The use of certain objects and the power attributed to them also played a key role in the Inquisition trial of Crispina Peres, a Kriston woman and trader from the trade settlement at Cacheu accused of engaging in 'African rites', 'witchcraft', 'superstition' and 'idol worship'. The evidence presented at the trial allows for a glimpse into the daily lives of residents of the port, illustrating the dynamics of reciprocal borrowing with regard to a variety of cultural practices in an Afro-Atlantic context. It reflects upon the close relations between Christianised residents and their African neighbours and clients, which had become cause for increasing concern for the Portuguese Crown and the Catholic Church. One of the denunciations made in the early 1600s refers to a 'white' Portuguese trader and co-residents having organised the traditional funeral or choro of a Pepel chief on the island of Bissau, selling a 'negro' woman to be sacrificed in his honour. ${ }^{143}$

The trial of Crispina Peres also underlines the importance of regional, gendered healing networks. By accusing a Christianised woman, the Inquisition wished to set an example, playing on popular sentiments which associated women with witchcraft. The accused, Crispina Peres, was of mixed parentage, that is Portuguese and African origin, her father a trader-settler from the Azores and her mother of Bañun descent. She was married to a

\footnotetext{
138 André de Faro, 'Relação de Frei André de Faro sobre as Missões da Guiné (1663-4)', in António Brásio, Monumenta Missionária Africana: África Ocidental, $2^{a}$ série (1651-84), Vol. 6 (Lisbon: Fundação Calouste Gulbenkian/Academia Portuguesa da História, 1992), 178-275; Mota, op cit. (note 111), 67-109.

139 Processo 801, António Fernandes (1548), (Inquisição de Lisboa IANTT). For further information on trials and denunciations in Guinea, see Ribeiro da Silva, op. cit. (note 127), Vol. 1, 146, 156, 159, 161, 254/5. On the demand for and sale of Christian relics such as crucifixes and rosaries in Angola and the activities of the Inquisition, see José da Silva Horta, 'Africanos e Portugueses na Documentação Inquisitorial, de Luanda a Mbanza Congo (1596-8)', in Encontros de Povos e Culturas em Angola, Actas do Seminário (Lisbon, CNCDP, 1997), 301-21; Selma Pantoja, 'Inquisição, Degredo e Mestiçagem em Angola no Século XVIII', Revista Lusófona de Ciência das Religiões, III, 5/6 (2004), 117-36; Kalle Kananoja, 'Healers, Idolaters, and good Christians: A Case Study of Creolization and Popular Religion in mid-Eighteenth-Century Angola', Journal of African Historical Studies, 53, 3 (2010), 443-65.

140 Processo contra Mestre Diogo, 233, Lisbon (1564), (Inquisição de Lisboa, IANTT).

141 Anguiano, op. cit. (note 106), 137, 269.

142 Ibid., 92/3, 137.

143 Denunciation of António Rodrigues Casquo, Livro de Denúncias, 205, Cacheu, 1609/1610, (Inquisição de Lisboa, IANTT).
} 
trader and former governor of Cacheu with Cristão Novo or New Christian roots, whose father had been the target of the Portuguese and Spanish Inquisitions directed against Sephardi interlopers. ${ }^{144}$

Numerous testimonies and eyewitness accounts made by Cacheu residents highlight common magico-religious beliefs and practices held by the local community. Crispina Peres was accused of conducting pagan rituals, which included the consultation and libation of animist shrines, the ritual sacrifice of animals, contracting the services of indigenous healers and the use of Mandé talismans, to which the inquisitors paid considerable attention. The accused, like other free women in the town, had paid regular visits to an animist shrine located in the Hot Town itself as well as to others beyond its perimeter in nearby (Pepel and Bañun) villages, making sacrifices and libations with blood and wine in the company of the 'heathen'. ${ }^{145}$ She had also sent her domestic slaves to the nearby Bañun ports close to Cacheu, where she had relatives, most likely of Bañun extraction, carry out these ceremonies. One of the witnesses declared that the principal healer from that town had actually been paid by the accused and other women to perform these rituals. His statement showed that Cacheu residents - and not only the accused maintained close relations of kin- and clientship with their African neighbours, including those described as 'witches' by clerics and the Inquisition. She was also said to send her slaves to sacrifice goats and chicken in order to have their blood sprinkled on her husband's vessel before he embarked upon trade voyages, a ceremony originally performed by the Bijagós which the Kriston had made their own. ${ }^{146}$ Her accuser, the visitador-geral [inspector general] of the Catholic Church, a priest and slave-trader born on the Cape Verde islands, had obtained this information from the testimonies and confessions taken from residents in a previous trial. ${ }^{147}$ She kept animist shrines in her own house, one of which he described as a window-frame hanging on the wall, meant to guarantee the longevity of one of her daughters. ${ }^{148}$

Crispina Peres had also sent for local healers when one of her daughters fell ill, in order to ascertain who, in the local African and Creole vernaculars, was 'eating', that is killing her, but unfortunately failed to save her. The same priest also denounced a number of free women from the town and from Cape Verde who consulted 'pagan shrines', illustrating the fact that such practices were common while underlining in this context the agency of women, who were prone to pursuing 'deviant' beliefs. ${ }^{149}$ Indeed, one of the witnesses stated that '... in Cacheu all the black women of the settlement and some white women keep shrines in their houses in which they have more faith than in God'. ${ }^{150}$ Witnesses also stated that local healers and diviners permanently resided in her house and that she always

\footnotetext{
144 For details on the trial, see Processo contra Crispina Peres, 2079, (Inquisição de Lisboa, IANTT). On women's roles, see Philip J. Havik, 'Walking the tightrope: female agency, religious practice and the Portuguese Inquisition on the Upper Guinea coast', in Williams, op. cit. (note 21), 174-91.

145 Testimony of Belchior Soares, Cacheu, 3 January 1661, Processo, op. cit. (note 143).

146 Capuchin missionaries also mentioned these rituals, see Anguiano, op. cit. (note 106), 134. Also see Cultru, op cit. (note 81 ), 220.

147 Processo contra Luis Rodrigues de Almeida, 8626 (1662); (Inquisição de Lisboa, IANTT).

148 Testimony of Gaspar Vogado, Cacheu, 11 January 1661; Processo, op. cit. (note 143).

149 Mary Elizabeth Perry, Gender and Disorder in Early Modern Spain (Princeton: Princeton University Press, 1990), and also by the same author, 'Finding Fatima, a Slave Woman of Early Modern Spain', Journal of Women's History, 20, 1 (2008), 151-67.

150 Testimony of Sebastião Vaz, Cacheu, 3 January 1661; Processo, op. cit. (note 143).
} 
followed their counsel. ${ }^{151}$ However, other Cacheu residents added that the accused was herself a witch, who had made her husband ill and kept him at home in order to stop him from travelling, and that he had requested the aid of healers in order to cure him. ${ }^{152}$

In this complex intrigue in which residents used the Inquisition to incriminate rivals and enemies, the figure of a male trader stands out who acts as a witness. Crispina Peres felt obliged to remind the court that Ambrósio Gomes, the wealthiest trader in Cacheu, who had denounced her inviting Bañun and Pepel healers into her house, was himself a well-known healer. Born in Cacheu of a New Christian father and of Bijagó descent on his mother's side, testimonies confirmed he was one of the most sought-after healers in Cacheu. When the accused was about to go into labour, she called his mother who lived across the river in the Bañun port of Guinguim to send her son over to assist her. He had learned his trade not only from his mother, who was a well-known healer, but also from itinerant Manding clerics and local women from the town, whose methods differed from those practiced by 'animist' healers. After giving her an unnamed potion to drink, he tied black and white cotton straps - supplied by Manding clerics - round her waist in order to guarantee a healthy birth; her child was expected to wear these straps around his arm until able to walk; in return for his services, he received a goat. Indeed, Ambrósio Gomes had confided to her that he wore these straps himself in order to protect himself against flesh-wounds resulting from battle and to make people whom he consorted with welldisposed. Most of the Kriston inhabitants of Cacheu wore these straps, the men to protect themselves in war, and the women to assist in childbirth. ${ }^{153}$ She added significantly, that the learned Cape Verdean priest who denounced her, also used the same straps to cure himself of a leg wound. ${ }^{154}$ Other cases of resident-traders wearing such amulets showed that the recourse to local healing methods was much more common than authorities were prepared to admit. ${ }^{155}$

\section{Final Considerations}

Over a period of several centuries the West African region under consideration formed the setting for intense and wide-ranging cross-cultural encounters. The ecology and geomorphology of the Upper Guinea coast, an area characterised by low-lying littoral areas dissected by a complex patchwork of rivers and creeks, was particularly suited to these dynamics. Inhabited by a large number of ethnic groups, the process of mandinguisation from the 1200s and the subsequent arrival of European and Cape Verdean traders, and settlers, and missionaries, provided the backdrop for conversion, accommodation and acculturation - as well as competition and conflict - between indigenous actors and

\footnotetext{
151 Testimony of Maria Mendes, ‘. . . a black woman from the island Santiago in Cape Verde. . .', Cacheu, 28-31665; Processo, op. cit. (note 143).

152 Testimony of Francisco Correa Tavares, Cacheu, 9 February 1663; Processo, op. cit. (note 143). She had also used herbal remedies to cure him, Testimony of Natalia Mendes, 10-1-1664, Processo, op. cit. (note 143).

153 Testimony by Crispina Peres, Cacheu, 23 August 1667; Processo, op. cit. (note 143). Talismans for women, djukó, were and are still used to guarantee a safe and healthy childbirth; see Carreira, Mandingas, op. cit. (note 39), 244. According to one of her ladino slaves, she also wore talismans herself, while forbidding her own slaves to use them; Testimony of Sebastião, Cacheu, 15-3-1663; Processo, op. cit. (note 143).

154 Damião Peres, 'Vicisitudes da Defesa Castrense de Cacheu [. . . ]', in Coelho, op. cit. (note 67), 265.

${ }^{155} \tilde{N} a$ Crispina stated that '.. all the residents as well as the missionaries and dignitaries of Cacheu cure themselves with them...', and that '... she wore nóminas because almost all the residents do the same ...', Testimony by Crispina Peres, Cacheu, 2 September 1667, Processo, op. cit. (note 143); Teixeira da Mota, op. cit. (note 111), 77.
} 
outsiders. By no means uniform, these processes gave rise to a progressive entanglement of indigenous groups with Mandé, Creole Cape Verdean and European stranger-settlers within the limits of the tidal range. The emergence of Manding settlements along the Gambia and the Geba River, and Afro-Atlantic trade settlements in littoral areas, starting with São Filipe, Cacheu, Geba, Buba, Farim, Bissau and Ziguinchor in the 1500s and 1600s, provided welcome operational bases linking Atlantic with African networks. Islamised Mandé traders and clerics and newly emerging Christianised social strata, such as the Kriston, mediated relations between Atlantic settlers, interlopers and African communities, connecting coastal, forest and savannah zones. ${ }^{156}$ In the process, lingua francas such as Mandé came to be widely disseminated in the West African region, while Creole dialects based upon a Portuguese lexicon with West African ethnic idiom and syntax formed in the Cape Verde islands (Kriolu) and the GBR (Kriol).

Although trade was the principal driving force behind these developments, the crosscultural dynamics that occurred were much more profound and complex, and did not follow uniform and linear paths. The forms of interaction and their organisation differed as communities migrated and settled as a result of shifting markets, conflict, famine, disease and epidemics. Given the links between Creole-speaking communities in the GBR and the Cape Verde archipelago, the issue of cultural exchange and creolisation constitutes a particular thread in scholarly work on the Upper Guinea coast. In an attempt to capture the 'extreme fluidity' of 'ethnically ambiguous' and 'multiple' (id)entities Trajano Filho proposed an 'open model' consisting of different stages of 'cultural mixing' for the region, each with their own specific dynamics, based upon the twin processes of primary and secondary creolisation. ${ }^{157}$ It attempts to circumvent the problems associated with categorisations, erroneously founded on ethnic criteria that often fail to overlap with linguistic and political units, thereby impeding an in-depth analysis of processes of spatial mobility and reciprocal assimilation. ${ }^{158}$ The formation of common 'cultural kits' which crossed geographical and ethnic divisions shared by different communities in coastal areas - a process which was already underway before European travellers visited the region reflected patterns of reciprocity associated with primary creolisation. ${ }^{159}$ The arrival and settlement of European stranger-traders on the coast in the 1440s would have initiated a process of 'secondary creolisation', that is the formation of a Creole society in littoral areas in the sphere of Portuguese influence. ${ }^{160}$

The problems inherent with the broadening of the creolisation approach and the use of the Caribbean as a 'meta-archipelago' for a supposed 'common creoleness' have been touched upon above. ${ }^{161}$ While the employment of the term as a cultural signifier for the Cape Verde islands where a Creole society indeed emerged seems quite justified, the case of the GBR is much more problematic in this respect. Although the notion of creolisation is appealing, the conclusion that twin processes of demographic and cultural creolisation would have occurred on the coast cannot be confirmed. ${ }^{162}$ In the absence

\footnotetext{
156 Havik, 'Traders, Planters and Go-Betweens', op. cit. (note 38), 197-226.

157 Wilson Trajano Filho, 'Uma Experiência Singular de Crioulização', Série Antropologia 343, Faculdade de Antropologia, Universidade de Brasília (2003), 9/10.

158 Ibid., 11/12.

159 Ibid., 13-7.

160 Ibid., 17. On Trajano's model, see Toby Green, The Rise of the Trans-Atlantic Slave Trade in Western Africa (Cambridge: Cambridge University Press, 2012).

${ }^{161}$ Palmié, op. cit. (note 19), 435.

${ }^{162}$ Havik, 'Kriol without Creoles', op. cit. (note 38), 41-74.
} 
of (continuous) demographic Euro-African creolisation, the processes rather centred on Creole Cape-Verdean-African and inter-African connections. After all, Europeans were generally lacking and intermarriage was limited to tiny niches, that is the Afro-Atlantic trade settlements, while interlopers (such as the lançados) were systematically absorbed into African societies. Indeed, it has been argued that despite the building of fortifications, these settlements formed part of an African space - and did not constitute Creole or European enclaves - and would remain so until the early 1900s. ${ }^{163}$ Also, the only 'mixed' social stratum, the Kriston who were to maintain a continuous cultural presence in the region from the $1500 \mathrm{~s}$, mainly resulted from inter-ethnic relations. ${ }^{164}$

Nevertheless, the dynamics which induced processes of cultural reciprocity in the form of shared 'cultural kits' do appear to apply to the present case study. They were both externally induced while having an internal, local momentum. The evidence given above shows that the mutual borrowing of notions and practices with regard to health, illness and healing had already begun before Euro-African contact, by means of weekly interethnic markets, migration, settlement and trade. Travelling Islamised Mandé clerics and traders disseminated healing and divination practices, substances and objects from the upper reaches of the Niger River to the West African littoral. Similarly, the itinerant Kriston and Catholic missionaries spread notions of healing and curing diseases across the region, connecting the densely forested intermediate zone to the limits of the tidal range. Household slavery, adoption and wardship of individuals from different ethnic groups in trade settlements further enhanced this process of circulation. As a result, popular and specialist healing techniques to treat a variety of health conditions were exchanged and assimilated by local populations. Islamised trade networks and Afro-Atlantic commerce promoted the circulation of healing substances and techniques via maritime routes, linking the region with the Americas, Europe and Asia. In the process, a mosaic of preventive and curative practices emerges in which holistic concepts and practices appear to incorporate biophysical and magico-religious realms.

The shift of settlement patterns, from a dispersed to a more localised mode, impacted upon the transfer of medical knowledge. Coastal and riverine settlements became multiethnic microcosms where these 'cultural kits' were assembled and refined over the centuries. Healing communities employing these kits provided care for locals and outsiders, thereby facilitating their survival in a tropical environment. They varied in accordance with location, demography and the external connections of sites. Along the Gambia River and in the Lower Casamance, Mandé, Bañun, Cassanga and Jola groups left their cultural imprints, whereas, along the Cacheu River, Pepel, Bañun and Jola influences dominated; in the ports of Bichangor, Buguendo and Guinguim, Bañun culture was a dominant force. Along the Geba River, the Pepel and Biafada made their presence felt, although Bijagó and Cape Verdean elements were also present. In the ports of Cacheu, Bissau, Farim and Geba, Manding influences were reinforced by their regional strongholds in the Gambia and the Kaabú federation. In Geba and Santa Cruz de Biguba, Biafada and Manding and also Fulbe traditions were apparent; the latter were also in evidence in the Nunez and Pongo Rivers further south bordering on the Futa Jallon, their religious centre. The main actors were the (male) Mandé itinerant traders, the djilas; (male) Mandé healers

163 Carlos Franco Liberato de Sousa, 'La Construcción Social del Espacio Urbano de Bissau (1765-1846)' (unpublished $\mathrm{PhD}$ dissertation, Centro de Estudios de África y Asia, Universidad de México, Ciudad México, 2001), 205.

${ }^{164}$ Havik, 'Traders, Planters and Go-Betweens', op. cit. (note 38). 
and diviners; the Kriston, above all women, that is the tungumás and ñaras; and local herbalists, healers and diviners, women and men, from Pepel, Biafada, Bañun, Cassanga, Bijagó and Jola groups.

In trade settlements in the GBR, the dynamics of reciprocal borrowing with regards to herbal remedies and magico-religious practice relied on the input of women through mutual-aid networks [Guinean Creole: mandjuandadi] based upon age-sets. Free Kriston women and their slaves collaborated with healers in surrounding areas and called upon itinerant practitioners. They mediated access to family-based Islamised, Christianised or 'animist' healers, who were consulted by a growing African and Atlantic clientele. Their therapies and resources, including herbal remedies and power objects, thus also found their way, with various modifications, across the Atlantic. Exogenous herbal and spiritual remedies, including Christian relics, were also incorporated into local African communities. Trade settlements were not only sites for obtaining supplies, slaves and commodities, but also for accessing care networks. Animist shrines located in or in the vicinity of trade settlements pertaining to neighbouring populations with whom the Kriston were related by kinship, such as the Jola, Bañun, Pepel, Bijagó, and Biafada, were also regularly consulted by a broad Afro-Atlantic clientele.

These processes which enabled 'cultural transfers' were heterogeneous and developed simultaneously in different locations in the region, producing complementary and competing healing narratives. ${ }^{165}$ The threat of disease and death was omnipresent on the African mainland, in trade-settlements and on slave ships, not only in the form of actual physical or mental ailments but also as a perceived threat. ${ }^{166}$ The different healing kits that circulated were intimately associated with everyday life, and assimilated into it, by all the social groups and actors in question. They centred on a relational approach to health with which both Africans and non-Africans could identify, being both adaptive and anchored in local traditions. Their composition changed over time, as cross-cultural networks shifted and new elements were incorporated and assimilated by clients and providers. Crucially, lingua francas, such as Mandé and Guinean Creole, provided common signifiers for the naming, understanding and dissemination of phytotherapeutic techniques and magicoreligious notions. Thus healing and illness constitute meta-narratives of cross-cultural interaction which can be traced over time in order to study the particular dynamics of these contact zones which not only constituted danger zones but also represented sites of cognitive innovation and creative practice.

165 Few, op. cit. (note 23), 132-46; 134.

166 Megan Vaughn, Creating The Creole Island: Slavery in Eighteenth-Century Mauritius (Durham, NC: Duke University Press, 2005). 